\title{
An Index to Measure the Integrity of Investment Companies Investing Responsibility
}

\author{
Don Andrew \\ University of Johannesburg, Auckland, New Zealand
}

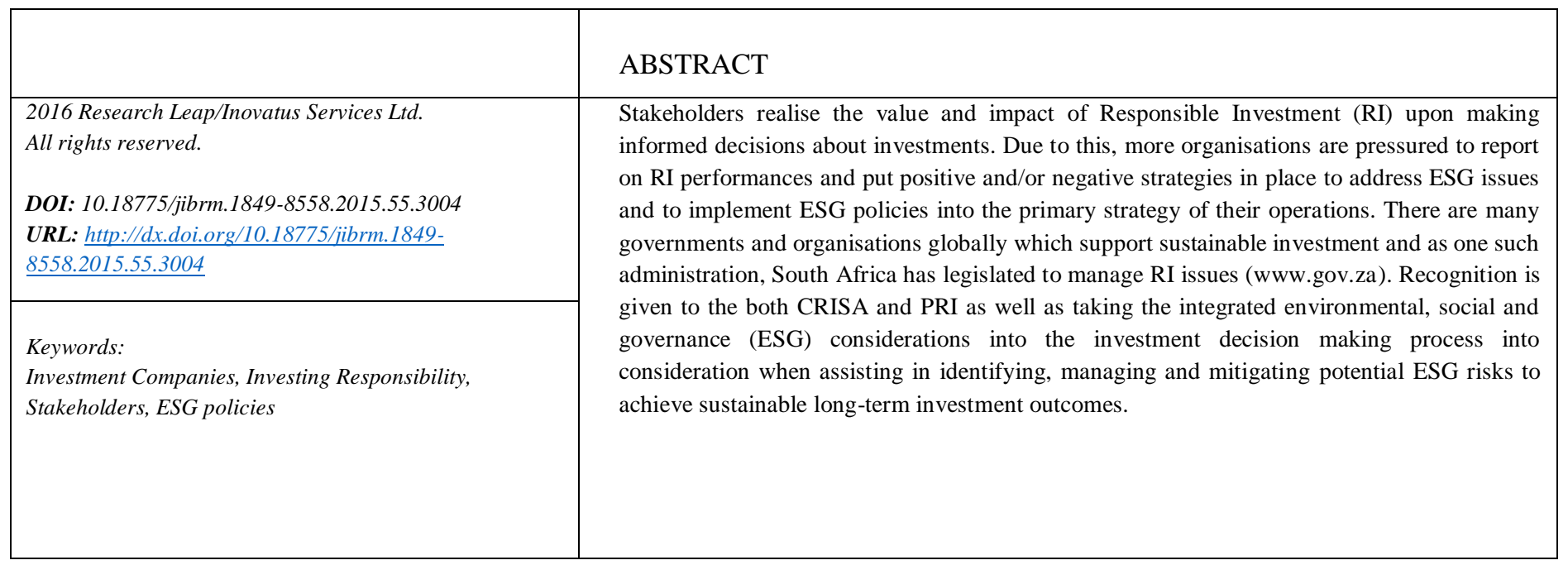

\section{Introduction}

Over the years, the South African government took a leading role, initiating programs aimed at responsible investing and the landscape was reshaped by the introduction of laws and principles aimed at promoting RI. Responsible investment frequently referred to as sustainable investment, (SI), has sufficiently increased momentum to propel itself into the mainstream of investments. As indicated by the Global Sustainable Investment Alliance, in 2016, responsible investment assets amounted to $26 \%$ of all assets professionally managed in Asia, Australia, New Zealand, Canada, Europe and the United States (McKinsey, 2019:2).

Asset managers are becoming more responsible by integrating environmental, social and governance (ESG) considerations into their investment processes (Camilleri, 2017:2). The challenge, however, is that it is not easy to survey or gauge the actual environmental and social impact of their decisions and their commitment.

\section{Responsible Investing}

South Africa not only introduced the Code for Responsible Investing (CRISA) in 2011, it is the second country, after the United Kingdom, to formally encourage investors to take into account environmental and social factors in conjunction with traditional financial analyses when settling on business and investment choices (Corporate Governance Review, 2013:305). In research done in 2017, $89 \%$ of the South African investors participated, revealed that responsible investing has become more important to them (Schroders Global Investor Study, 2017:14).

Responsible investment came into existence because of environmental issues including global warming and climate change. Environmental issues refer to energy consumption, the availability of usable water, different forms of pollution, waste management and environmental problems which are created by organisational decisions, pollutants, toxic gas emissions, improper waste management and disposal (www.cfa.org). These environmental challenges become potential risk factors for investors, as environmental problems can result in losses. Initiatives to repair environmental damage such as pollution carry financial costs, thus investments towards the prevention of environmental problems reduce the risk of eventual financial losses (Camilleri, 2017).

The United Nations has played a significant role in promoting RI. The concept of RI has spread worldwide among various institutions due to the Principles for Responsible Investing (PRI) developed in 2006 under the auspices of Kofi Annan, the former 
Secretary General of the United Nations. PRI has a foundation of six principles (www.unpri.org). These principles form guidelines for the more than 1500 of its signatories, who incorporate these principles to consider ESG factors in their investment strategies (www.unpri.org). Stakeholders are becoming more aware of the environmental, social and governance related issues and are inclined to expect investment managers to invest their money in organisations that follow ESG principles (Syed, 2017:2).

As stakeholders realise the value and impact of RI, they want to make informed decisions about investments. These stakeholders include all organisations, businesses, groups, institutions and individuals that influence or are being influenced by an organisation's decisions or its operations in various ways, such as contributors to pension funds, the employees, customers, suppliers, the government and shareholders (Carroll, 1991:44). As a result, more organisations are pressured to report on RI performances and positive and/or negative strategies to address ESG issues and to implement ESG policies into the primary strategy of their operations.

However, the impetus for these changes is not solely from the private sector. There are many governments and organisations globally which support sustainable investment and as one such administration, South Africa has legislated to manage RI issues (www.gov.za). Table 1 reflects a list of selected legislation on ESG matters in South Africa.

Table 1: Selected legislation in South Africa relevant to ESG matters

\begin{tabular}{|l|l|l|}
\hline \multicolumn{1}{|c|}{ Environment } & \multicolumn{1}{|c|}{ Society } & \multicolumn{1}{c|}{ Governance } \\
\hline $\begin{array}{l}\text { National Environmental } \\
\text { management Act (1998) }\end{array}$ & $\begin{array}{l}\text { Broad-based Black } \\
\text { Economic Empowerment } \\
\text { Act (2003) }\end{array}$ & $\begin{array}{l}\text { Pension Funds Act } \\
\text { (1956):Regulation 28 }\end{array}$ \\
\hline $\begin{array}{l}\text { Environmental Conservation } \\
\text { Act (1989) }\end{array}$ & $\begin{array}{l}\text { Unemployment Insurance } \\
\text { Act (2001) }\end{array}$ & Companies Act (2008) \\
\hline National Water Act (1989) & $\begin{array}{l}\text { Basic Conditions of } \\
\text { Employment Act (1997) }\end{array}$ & $\begin{array}{l}\text { Consumer Protection Act } \\
\text { (2008) }\end{array}$ \\
\hline The Constitution: Section 24 & $\begin{array}{l}\text { Skills Development } \\
\text { Act(1998) }\end{array}$ & National Credit Act (2005) \\
\hline
\end{tabular}

Source: Mans-Kemp and Viviers $(2016,106)$

\subsection{Responsible Investing in South Africa: Theories and Findings}

South Africa has taken RI serious when compared to its emerging market peers and is viewed as a leader in this field. Responsible investment purposes are distinct from conventional investment in the sense that these investment portfolios balance consideration of both social and financial factors (Van der Ahee $\&$ Schulschenk, 2013:3). This form of investment has a powerful appeal to certain investors. There are many factors that inspire investors to choose RI; they include environmental and social concerns, such as global warming and climate change (Yan, Ferraro, and Almandoz, 2018:25).

\subsection{Responsible Investment (RI) and Environmental, Social and Governance (ESG) Factors}

Both ESG and RI have fundamentally similar objectives, but they differ in the sense that they employ different strategies to accomplish these objectives. The ESG investment approach is about identifying ESG compliant organisations and employing a positive or inclusionary strategy $(\mathrm{Li}$, Sherrerd, \& Treussard, 2018:7).

\subsection{The Process of Investing Responsibly}

After the investor has met with an investment institution, a portfolio manager draws up a socially responsible portfolio. The manager has to select suitable investments from a global market and then employs screening methods to identify organisations, which comply with ESG criteria. These criteria include ethical, social, religious, economic, and environmental issues as well as governance of the organisation. In some cases, the investor will specify additional preferences. Included among the screening techniques used are negative or exclusionary methods which exclude organisations that deal in products or processes deemed objectionable. These would be organisations which manufacture firearms or weapons, cigarettes, alcohol or tobacco; organisations that contribute to pollution or organisations involved in operations which cause harm to the environment (Gómez-Bezares, Muñoz, \& Vargas, 2013:106).

The second method (positive or inclusionary) is to identify organisations, which contribute to ESG issues; these companies are producing acceptable processes or products (Berry \& Junkus, 2013). The organisations selected are environmentally conscious, contribute to society's well-being, have proven human rights records, or invest in social and environmental initiatives (Berry \& Junkus, 2013). Regardless of the method used to select investments, the prime objective is that the chosen organisations are associated with efforts to contribute to environmental and societal issues.

The Code for Responsible Investing CRISA, is voluntary code of practice that serves as a framework or a guide to aid investment companies involved in RI. It describes the governance obligations of institutional investors relating to the entire administration or governance framework. It endeavours to assist the integration of ESG concerns into sustainable investment decisions (www.asisa.org.za).

\subsection{The Role of ESG Managers}

Portfolio managers have the fiduciary duty to serve their investors by managing the invested money with discretion and market acumen. Generally, an ESG portfolio manager identifies ESG compliant organisations and invests in those companies. The expectation is that these organisations are committed to ESG issues and deliver benefits to the community, by means of 
their product offerings, creating employment, promoting equality and demonstrating social responsibility. These types of organisations are kept in the portfolio especially when they perform financially in addition to achieving non-financial objectives and responsibilities. It is the responsibility of the portfolio managers to monitor and evaluate which organisations are genuinely active in addressing issues associated with equality, human rights, the environment good governance and other related ESG issues (Lynx Investment Advisory, 2018).

\subsection{The Need for Disclosure}

The South African Roadmap was formulated as a complimentary practical guide to portfolio managers to empower them to cooperate with investment consultants on ESG incorporation. (www.unepfi.org). In the last three years, the South African financial industry has experienced a series of damaging revelations, such as numerous corruption activities in which senior government officials were involved and private sector corporate governance scandals. The auditing firm, KPMG, was operating under dubious circumstances resulting in a distrust of auditing firms (Kern-Stone \& Mishra, 2019:57). In other cases, rules and regulations were ignored (Snyman-van Deventer \& Thabane, 2018). This situation shows that transparency and improved oversight measures are a necessity in all spheres of the financial industry. In order to restore confidence in this sector, regulators, investment consultants and portfolio managers need to adopt the Roadmap to re-establish South Africa's status as a leading figure in responsible investment. (www.unepfi.org). Presently, while JSE-listed companies do disclose on ESG issues as set out in the King IV (guide pertaining to integrated reporting) they do so voluntarily on the Global Reporting Initiative (GRI). However, this is not an adequate solution for transparency or compliance (Van der Ahee \& Schulschenk, 2013:2).

\subsection{Avoiding False Claims of Compliance}

In South Africa there is a definite need to construct regulations and standards around responsible investing which fit local conditions. Table 2 outlines certain of these standards.

Table 2: Setting standards to avoid false ESG compliance claims

\begin{tabular}{|c|c|c|}
\hline ta to be displayed publicly & $\begin{array}{l}\text { An ESG assessment of } \\
\text { companies }\end{array}$ & $\begin{array}{l}\text { ESG benchmark } \\
\text { to be set }\end{array}$ \\
\hline $\begin{array}{l}\text { Organisations and institutions which } \\
\text { announce that they comply with kesponsible } \\
\text { investing must be mandated to publicly } \\
\text { disclose information and procedures } \\
\text { employed. The data supplied must then be } \\
\text { measured by means of a standardised rating } \\
\text { index, which is designed according to an } \\
\text { approved system and can be used } \\
\text { universally. Instead of only disclosing data } \\
\text { about investing practices, additional } \\
\text { information must be supplied such as } \\
\text { workforce demographics and particulars } \\
\text { about the environmental impact. }\end{array}$ & $\begin{array}{l}\text { These companies must } \\
\text { embrace and invite external } \\
\text { rating agencies, which can } \\
\text { assess the practices and } \\
\text { initiatives and then compile a } \\
\text { report, which includes their } \\
\text { index rating according to the } \\
\text { standardised universal } \\
\text { criteria. This procedure works } \\
\text { similar to credit rating } \\
\text { agencies, which calculate } \\
\text { creditworthiness. }\end{array}$ & $\begin{array}{l}\text { Portfolio managers } \\
\text { can only claim to be } \\
\text { responsible } \\
\text { investors when a } \\
\text { certain score is } \\
\text { achieved according } \\
\text { to the standardised } \\
\text { rating index and } \\
\text { when verified by } \\
\text { independent rating } \\
\text { agencies. }\end{array}$ \\
\hline
\end{tabular}

Source: Nelson (2018:3)

\section{Research Problem}

The choice of indicators to measure ESG is vast and as such, there is no universality among institutions that measure SRI when choosing from these indicators. Indicators include ethical considerations, economic issues, social or environmental dimensions. Sustainability impact assessment (SIA) can play a major role when it comes to the decision-making process for major sustainable investments (Laedre et al., 2015:98).

The purpose of this research is to develop an appropriate structure which would provide a more holistic view as well as the ability to gauge the integrity of organisations who claim to be responsible investment compliant. The research problem therefore can be identified as a study to develop an appropriate system or index, which would provide a more holistic perspective and the ability to quantify the integrity of organisations who claim to be responsible investment compliant.

\section{Research Objective}

The research objectives derived from the research question are:

\subsection{Primary objective}

The primary objective is to identify a suitable index which would be used to test the claims made by asset management companies that they are investing responsibly.

\subsection{Secondary objective}

To determine how this index could be used to benchmark any company in the financial services industry against their peers when it comes to responsible investment.

\section{Responsible Investment: An Overview}

The global financial crisis of 2008 indicated the importance of responsible investment practices and the need to concentrate on the long-term value of investments rather than short-term performance (Urwin, Worldwide \& Woods, 2012). Responsible investments are beneficial for both the investors and companies (Fulton, Khan \& Sharpies, 2012). The factors considered for responsible investment decisions are the compliance with sound environmental, social and governance practices (www.unepfi.org). Many companies have integrated their ESG information into the capital allocation process (Khan, Serafeim \& Yoon, 2015). The positive reputations of companies on ESG matters help in the better share price performance of the company, the achievement of superior financial and investment performance over time and can lead to employees having stronger relationships with their employees (Mansberger, 2012). Companies such as Enron, Lehman Brothers, BP, Monsanto, and Volkswagen (VW) are examples of harmful and expensive corporate negligence or malfeasance that created significant economic, environmental, or societal hazards which eventually resulted in the collapse of some of these organisations (Sulkowski, 2015). The VW emissions scandal that took place in 2015 was an example of how the ESG formula could have provided a warning to investors when the company started 
pursuing short-term profits to the detriment of long-term benefits (Rintoul, 2015). In the UK, companies such as BP, Standard Chartered, Tesco, Compass Group, Shell and HSBC have been involved in scandals and companies such as Polly Peck, Equitable Life, South Sea Company, Overend Gurney \& Co, BCCI, Northern Rock and RBS have collapsed due to poor ESG practices (Sulkowski, 2015).

The corporate scams, according to Sulkowski (2015), include evading tax, consuming corporate welfare, the funding of purported unethical think tanks, privatising profit and nationalising market failures. Enron, the energy giant based in Houston became bankrupt in 2001 due to a massive accounting fraud scandal (Maharaj, 2012). Volkswagen, on the other hand, lied about its emissions and had to issue a recall of some of its car models. Although these emissions caused the deaths of people many consumers still remained loyal to the brand (Sulkowski, 2015).

The traditional corporate governance structures, risk management and internal controls do not address the changes and challenges faced by companies and directors (Bostrom, 2013). Even though Lehman Brothers, which filed for bankruptcy in 2008 due to fraud by top executives and the auditors Ernst \& Young, sparked the worldwide financial crisis, they were not prosecuted by the Department of Justice or the Securities and Exchange Commission (Maharaj, 2012). The Deepwater Horizon oil spill by BP in 2010 created a negative social responsibility image for the company as there were no ethical obligations to protect the environment (Kanso, Kitchen \& Nelson, 2019).

Responsible investment means investing in themes related to sustainability, such as green technology, clean energy or sustainable agriculture and exclusion from specific sectors, organisations or practices dependent on certain ESG criteria (Mansberger, 2012). In the current global financial climate, sustainable or green investment is gaining importance in the financial markets due to the superior risk-adjusted performance (Marchand, 2012). Social responsible investment in the 1960s was driven by religious issues about ethics and could be named as ethical investing (Fulton and Khan, 2012). Today the socially responsible investment is driven by concerns regarding ESG (Cunha \& Samanez, 2013).

Responsible investment has increased in the last two decades with varying levels of increase in different countries. For example, when the investment in sustainable assets in the United States represented more than $11 \%$ of the total investments in 2007, the responsible investment in Germany during the same year was only $1 \%$ (Peylo, 2012). According to Connakker and Madsbjerg (hbr.org), at the beginning of 2018, USD\$11.6 trillion of all assets under management, one $\$ 1$ of every $\$ 4$ invested in the United States was managed according to ESG investment strategies.
Fund managers are more vigilant in investing in green, social and ethical funds due to the reduced risk of loss in a credit crunch scenario. In stock exchanges around the world, there is a higher awareness of sustainability oriented issues; there is the advancement of products and services to responsible investors, development of specific markets for sustainable investments and the motivating force to have higher norms of sustainability among listed companies (Cunha \& Samanez, 2013). With the increased social screening of companies for investment decisions and responsible investment practices, institutional investors have lowered the total risk and added value to the portfolio (Mercer, 2009).

\subsection{Responsible Investment and Investor Behaviour}

Institutional investors have large and diversified portfolios with substantial company ownership and solid motivating forces to screen and impact organisations (Bekjarovski \& Brière, 2018). Effecting change is easier for majority shareholders as the threat of managerial replacement is credible but scattered shareholders also have a range of tools at their disposal to challenge management when displeased with corporate policy. Shareholder activism can take various forms:

- exit (sells shares, take an offsetting bet)

- vote (form coalition/express dissent/call back lent shares)

- engage behind the scene with management and the board

- voice displeasure publicly (in the media)

- propose resolutions (shareholder proposals) or

- initiate a takeover (acquire a sizable equity share).

\subsection{Investing: Ethics and Morals}

Investing with ethical concerns has clearly gone from marginal to mainstream (Revelli, 2017), but there are still some issues in embracing RI principles. There is no single and universal meaning of what criteria a mutual fund should follow to be considered an ethical or socially responsible fund. Ultimately, the level of heterogeneity in the criteria utilised by RI funds mirrors the diversity of investors' values.

The results of Silva and Cortez (2016) propose that the performance of green funds is higher in crisis periods in contrast with non-crisis periods. As indicated by the results of a study conducted by Leite and Cortez (2015), the underperformance of green funds relative to conventional funds during non-crisis periods, which supports Silva and Cortez's (2016) findings, was driven by funds that used negative screening. The study further revealed that RI funds that used positive screens perform correspondingly to conventional funds across fluctuating market conditions. Positive socially responsible features of companies result in lower risk in market crisis periods, and this is a factor that can explain RI popularity.

Mallett and Michelson (2010) conclude that there is no real contrast, in terms of performance, between green funds, RI and index funds, whilst Climent and Soriano (2011) finds that green 
funds have lower performance (or similar if we consider a shorter sample period) than conventional funds with similar characteristics. The US green mutual funds generate lower returns and similar risks relative to US conventional mutual funds (Silva \& Cortez, 2016). Muñoz, Vargas, and Marco (2014) shows performance parity between green and other SRI funds, regardless of the market cycle (crisis or non-crisis). Ibikunle and Steffen (2015) suggests that green funds significantly underperform their conventional peers, while there are no statistical differences between green and black (natural resources and fossil energy) funds. More recently, Silva and Cortez (2016) indicates that the US and European global green funds tend to underperform the benchmark, especially in noncrisis periods.

\subsection{Measuring Responsible Investment}

Studies done from Oxford University, Deutsche Asset \& Wealth Management, Morgan Stanley Institute for Sustainable Investing and the United Nations Environment Programme Finance Initiative Various reveal that organisations integrating solid corporate social responsibility approaches and practices are performing better. (www.unepfi.org). A study by Deutsche Asset \& Wealth Management (2015), data in excess of 2000 empirical studies, revealed overwhelmingly that a positive association exists between ESG standards and organisational financial performance (institutional.dws.com).

In 2011, Nel (2011), used Capital Assets Pricing Model (CAPM), as a model employed to calculate the rate of returns on an investment in relation to its risk factors. However, scholars are not in agreement as to the best method of measuring investments. Jones et al., (2008) observed that investors do actually invest in ethical funds, although they may not perform any better than conventional investment. Popular investment theory suggests that investors want optimum returns in relation to the level of risk. This observation contributes to another factor to be considered when measuring RI funds. It can then be argued that investor preference plays another major role in the world of RI. Jones et al., (2008) then states that other driving forces are also at play in the choice of investment. There is a trend like financial sacrifice which relates to an interest in ethical funds. Thus a need is created to research and to determine the factors that stimulate ethical investing in the South African context.

The Arbitrage Pricing Theory (APT) is another model which is commonly used to measure SRI as a substitute to the CAPM. The distinctive factor of this theory is that it relies less on assumptions as compared to the CAPM and utilises real world measurements. It is thus a simplified model as opposed to the CAPM (Huberman, 2005). Measurements in the CAPM entail a market portfolio to calculate the beta coefficient whereas the APT does not rely on these factors which gives APT a more flexible approach. CAPM was designed for measuring single periods, whereas the ATP does not have such restrictions and can be utilised to measure multiple periods.
Another significant model worth mentioning is the Modern Portfolio Theory (MPT). For this model, portfolios (investments and assets) are chosen that generate maximum return at the lowest risk (Markowitz, 1991). This approach requires that the portfolios must be constructed optimally to perform on the upper bracket for long periods thus negating the risks (Elton, Gruber $\&$ Blake, 1995). This theory has its fair share of critics who set out to challenge this philosophy, although its application is rather widespread.

According to research by Kurtz (2005), diversification does in fact deliver increased return and at the same time the risk factor was reduced. He elaborated by stating that the Domini 400 Social Index (DSI) outperformed the S\&P500 Index over 15 years prior to December 2004 by $1.25 \%$ annually. DSI refers to the 400 investments that comply fully with ESG principles and the S\&P500 Index refers to the top 500 performing investments. A negative aspect of MPT is that it relies on diversifying of investments. Thus when diversification is limited, the risk factor increases accordingly. To negate the factors of risk, intensified screening is required. Furthermore, the model rests on the experience and skills of the investment managers to choose the best investments for diversification (Sauer, 1997).

The Treynor ratio was developed to measure risk-adjustment of performances of portfolios. It was developed with the intention of taking into consideration the risk created by market volatility as well as unsystematic risks, which are particular to securities in portfolios (Treynor, 1965). In essence, the Treynor ratio compares the portfolio returns against the market rate return. The two risk components previously mentioned are called alpha and beta respectively.

The alpha in this case means the higher the risk, the higher the return and the higher the volatility of the portfolio over a time period. The beta is the slope which represents the sensitivity of the portfolio relative to the market portfolio. This slope has a range from -1 to 1 . A high score of sensitivity is shown when the market portfolio is volatile and this occurs when the market is fluctuating (Treynor, 1965). In other words, Treynor's ratio gauges a portfolio for every unit of risk.

\subsection{Strategies in Responsible Investment}

Optimising performance by either securing the maximum future return for any given risk level or decreasing risk for a set return objective, at the same time being exposed to fundamental uncertainty about the future is the decisive strategy.

The financial industry is driving its values and practices into the real economy while endeavouring to improve the monetary circumstance by turning a sustainable investment into an opportunity. Institutional investors consider two fundamental criteria as sustainability aspects when making investments: 
- Complying with, for the most part, perceived universal and national standards or specific qualities characterised by their own organisation within their investment activity,

- Improving the risk/return profile of investments, advancing sustainable development and business practices (Oekom Research, 2013).

\subsubsection{Negative or Exclusionary Screening}

According to UNPRI, the most common type of ESG screening is negative or exclusionary screening. This implies that specific sectors, organisations or practices are excluded from a portfolio based on specific ESG criteria. This exclusion would relate to companies who derive revenue from "sin stocks" such as tobacco, weaponry, pornography, gambling, alcohol and animal testing (www.unpri.org). Exclusionary and negative screening is the most applied strategy of investing responsibly, totalling an amount of USD $\$ 15$ billion in assets in 2016 globally, as indicated by the Global Sustainable Investment Alliance (GSIA) (www.mckinsey.com).

The GSIA provides an overview that is becoming the market standard. Besides negative screening, Table 3 depicts a few other RI strategies that could be applied:

Table 3: Responsible investing strategies

\begin{tabular}{|c|c|c|c|c|}
\hline $\begin{array}{l}\text { Positive best-in } \\
\text { class screening }\end{array}$ & $\begin{array}{l}\text { Norms-based } \\
\text { screening }\end{array}$ & $\begin{array}{l}\text { ESG } \\
\text { Integration }\end{array}$ & $\begin{array}{l}\text { Sustainability } \\
\text { theming }\end{array}$ & $\begin{array}{l}\text { Corporate } \\
\text { engagement and } \\
\text { shareholder action }\end{array}$ \\
\hline $\begin{array}{l}\text { Identifying sectors, } \\
\text { companies or } \\
\text { projects and } \\
\text { investing in them } \\
\text { on account of their } \\
\text { positive ESG } \\
\text { performance with } \\
\text { respect to industry } \\
\text { peers. }\end{array}$ & $\begin{array}{l}\text { Comparing potential } \\
\text { investment } \\
\text { opportunities in } \\
\text { companies against } \\
\text { minimum standards } \\
\text { of business practice } \\
\text { dependent on } \\
\text { universal norms. }\end{array}$ & $\begin{array}{l}\text { The } \\
\text { consideration } \\
\text { of ESG } \\
\text { factors in the } \\
\text { investment } \\
\text { decision } \\
\text { making } \\
\text { process. }\end{array}$ & $\begin{array}{l}\text { Identifying } \\
\text { themes that } \\
\text { are } \\
\text { specifically } \\
\text { related to } \\
\text { responsible } \\
\text { investment. }\end{array}$ & $\begin{array}{l}\text { Direct engagement } \\
\text { by shareholders to } \\
\text { influence corporate } \\
\text { behaviour including } \\
\text { proxy voting guided } \\
\text { by ESG principles or } \\
\text { guidelines. }\end{array}$ \\
\hline
\end{tabular}

Source: Zandbergen \& Moret (2018).

\subsection{Responsible Investment Indicators}

Investors expect high financial returns, but investors also want to assure themselves that the organisations that receive their money are in fact contributing and implementing strategies to enhance environmental protection and addressing social and ethical issues. Measurable criteria must therefore exist to enable investors as well as investment and fund managers to select investments that are in line with their personal values, as well as their financial goals (Inderst \& Stewart, 2018).

JSE SRI index measures organisation's compliance to SRI. A list of these companies will appear in the JSE SRI index affording investors the opportunity to look at different indicators of an organisation. These indicators include sustainable practices, policies, environmental conflicts and ethics (www.jse.co.za). The JSE SRI index is guided by the principles of triple bottom line, namely environmental, social and economic sustainability and reinforced by good corporate governance (www.jse.co.za).

The first pillar of environmental sustainability is concerned with the resources consumed by the company and this pillar ensures that negative impacts to the environment are minimised or reduced and continuous improvement in achieved (www.jse.co.za). The second pillar of economic sustainability is concerned with the long-term growth rather than the short-term performance of the organisation and this pillar ensures the longterm viability of the business.

The final pillar of social sustainability is concerned with promoting social upliftment and development, reduction of poverty, empowerment, equity in employment, health and safety of employees, fair labour practices and diversity (www.jse.co.za). The JSE SRI ensures that the organisations have a responsibility towards the society and investors along with ensuring the creation of a profitable portfolio with better financial performance (Mutezo, 2013). The objective of the JSE SRI index is to perform a holistic assessment of company policies, integrate the principles of good corporate governance, facilitate investors to consider non-financial risk variables when making an investment decision and develop sustainable business practices in South Africa (Mutezo, 2013).

The United Nations established PRI which lists six basic ESG principles that influence the performance of investments and are considered by all investors (Cunha \& Samanez, 2013). The first principle states that ESG issues need to be incorporated into investment analysis and decision-making processes. The second principle states that companies are asked to be active owners and integrate ESG in the practices and policies of ownership. The institutional investors are approached to look for proper exposure on ESG issues in the organisations they invest in and this is when the third principle is applied. The fourth principle states that all institutional investors need to advance the implementation and acceptance of the PRI principles in the investment industry. The fifth principle maintains that the effectiveness in implementing the principles will be achieved through working together. The sixth principle states that the activities and progress in the implementation of the principles needs to be reported by all signatories (www.unpri.org).

The principles of PRI are based on the assumption that the investment performance is affected by environmental, social and corporate governance issues (Eccles, 2010). The ESG challenges present opportunities for companies to create value by innovating products and processes that are sustainable and increase their revenue from that stream (www.pwc.co.uk). ESG considerations are on the fringe and not in the heart of investment practices of the institutional investors (www.pwc.co.uk). The six principles give a framework to institutional investors to create value in the long term and in 
sustainable markets (www.unpri.org). As part of responsible investing, institutional investors disclose details of fund governance structure and with due diligence take up risk analysis and portfolio monitoring for the funds (www.unpri.org). When the companies take up sustainable development then the chances of a stable and inclusive global economy are higher and there is a tremendous potential to achieve the goals of the United Nations (www.unpri.org).

The United Nations principles of responsible investing came into effect due to the significant damage businesses has caused to the environment and because addressing the damage was costlier than using resources in a sustainable manner (Engshuber, Krumsiek \& Burrett, 2011). The PRI has created a global awareness about investing responsibly and increasing the progress of investors investing in responsible companies (www.unpri.org). The PRI aims to influence companies in reducing greenhouse gas (GHG) emissions, contamination of land, eco-efficiency and waste management, reducing air pollution and water use to mitigate the overall environmental costs and damages (Engshuber et al., 2011).

Social issues in the PRI include health and safety, supply chains, human rights, labour conditions, treatment of employees and fair treatment of customers and communities (www.pwc.co.uk). Governance concerns include responsible investment sense, anti-bribery and corruption and business ethics and transparency (www.pwc.co.uk). Eccles, (2010) argued that PRI was introduced four decades ago, it would have had an important impact in the business society and could have reduced the damage to the environment, ethics and fair treatment of people of all races. The barriers to responsible investment need to be dismantled and all companies must be asked to incorporate ESG issues into their business as it is important to the performance of a company (www.unpri.org). Table 4 reflects a list of South African asset managers who participated in this study and whether they are signatories to PRI or CRISA. In some cases, some asset managers are not signatories to either code.

Table 4: South African Signatories to the PRI and CRISA codes.

\begin{tabular}{|c|c|c|c|}
\hline Both·CRISA-and·PRI $\propto$ & PRI $\alpha$ & CRISA $\propto$ & Neither-PRI'or'CRISA $\propto$ \\
\hline Afena-Capitalo & Visio Capitalo & Foordo & Abaxdo \\
\hline Allan-Grayo & 0 & Perpetua ${ }^{\prime}$ & Ashburtono \\
\hline Cadizo & 0 & SENTIOO & First:Avenueo \\
\hline Catalysto & 0 & Taquanta: & Meagos \\
\hline Coronation: & o & Truffleo & Sesfikile-Capitalo \\
\hline Elemento & 0 & o & $\circ$ \\
\hline Future-growtho & o & o & o \\
\hline Investeco & o & o & $\circ$ \\
\hline Kagisoo & o & o & o \\
\hline Mergence $\circ$ & o & o & o \\
\hline Mianzoo & 0 & o & o \\
\hline Oasiso & o & o & o \\
\hline Old:Mutualo & - & - & o \\
\hline Presciento & o & 0 & o \\
\hline Prudentialo & o & o & o \\
\hline PSG $\circ$ & o & $\circ$ & $\circ$ \\
\hline Sanlamo & 0 & o & o \\
\hline STANLIB 0 & \% & o & o \\
\hline
\end{tabular}

\section{Research Methodology}

Positivism research paradigm is used in reality as external (independent) from the researcher or observer view that factual knowledge should be trusted is adopted. A qualitative research approach was taken where the primary method used to obtain data was a survey through questionnaires sent to all South African asset and fund managers. The data was analysed using the appropriate statistical procedures (Austin \& Sutton, 2014:436).

A primary (questionnaire) as well as secondary data collection methodology was employed. Comparisons were made by the companies listed based on four indicators identified.

\subsection{Data Collection}

The primary data for the study was collected through the survey method by using standardised, structured, self-completion questionnaires. Figure 1 outlines the framework used to direct the collection of the data.

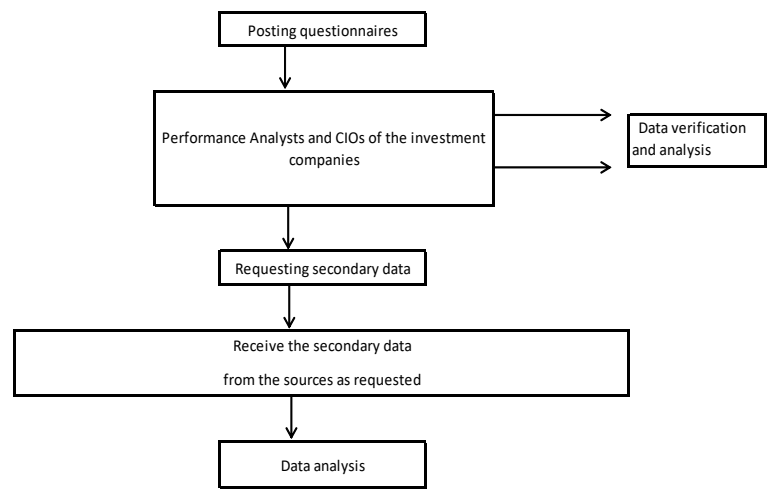

Figure 1: Research methodological framework diagram

\subsection{Data Collection Instrument}

A responsible survey questionnaire was employed as the data collection instrument. The questionnaire for this study contained 29 questions that dealt with all three aspects of responsible investments: environmental, social and governance (Jones, Baxter \& Khanduja, 2013). A rating scale was applied to the responses in order to extract quantitative data. Data were collected from asset managers through a self-administered questionnaire, called the Responsible Investing survey, which has been developed by Alexander Forbes Investments. The Responsible Investing survey gauges the conduct approach of asset managers by monitoring their incorporation of ESG factors into their investment decisions.

The questionnaires were divided in two groups, both sets then independently investigated to verify any corresponding properties. This method resulted in time-saving and costeffectiveness, despite the fact that questionnaires have disadvantages (Anney, 2014:276). 
The data required were:

- The responses provided by asset and fund managers to the Alexander Forbes Investments Responsible Investing survey

- Vuyo Jack's Empowerdex ratings - verification data received from each manager surveyed.

- CRISA / PRI - confirmation of the signatories to both codes were sourced from the Alexander Forbes Investments 2016 RI survey as well as from the managers themselves.

\subsection{Data Collection Process}

Questionnaires were sent to representatives and staff of all asset and fund managers domiciled in South Africa. A total of 42 questionnaires were received. For the purposes of this study, the assurance was given to the respondents that anonymity would be maintained. Consequently, participants are referred to as Case 1 , Case 2 and so on.

\subsection{Population}

All listed financial services institutions in South Africa were recognised as the target population. This study specifically looks at South African asset and fund managers. The following asset managers were among those who responded to the survey:

Table 5: South African asset managers

\begin{tabular}{|c|c|c|c|}
\hline Abax & First-Avenuex & Oasisa & Sesfikile Capitalo \\
\hline Afena.Capitala & Foordx & Old-Mutual $x$ & STANLIB $\propto$ \\
\hline Allan-Grays & Futuregrowth & Perpetua & Taquantax \\
\hline Ashburtona & Investec $\alpha$ & Prescient $\alpha$ & Truffle $\alpha$ \\
\hline Cadiza & Kagiso: & Prudentiala: & Visio-Capitala \\
\hline Catalysta & Meago $\alpha$ & PSG & $a$ \\
\hline Coronationa & Mergence $\alpha$ & Sanlam $: x$ & 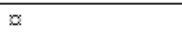 \\
\hline Elementa & Mianzo: & Sentio $x$ & $\infty$ \\
\hline
\end{tabular}

\subsection{Sampling}

Non-probability, purposive sampling, consisting of individual asset managers were used.

\subsection{Data Analysis}

The data from the questionnaires were statistically interpreted and analysed using a software programme known as Statistical Package for the Social Sciences (SPSS). The data were interrogated and coded that descriptive statistics in the form of frequencies, mean scores and standard deviation were generated, after which the results were displayed in tables and diagrams.

\subsection{Coding Structures}

A thematic data breakdown stratagem was employed in order to assess the collected information as it is more flexible. The data collected from each respondent was reviewed, compared and collated. This was done with the intention to recognise any resemblances across the data sets.

\subsection{Ethical Considerations}

According to Connelly (2014:54), individuals additionally are responsible to ensure the study participation is voluntary and potential subjects have all the information they need to make an informed decision concerning study participation. These aspects incorporate privacy and confidentiality, informed consent, justice, autonomy and value. The data for this study was received from Alexander Forbes Investment. Permission to use the data was granted on condition that the identity of the asset managers would be concealed.

\subsection{Privacy and Confidentiality}

Research data will be kept confidential and protected. The participants have the right to privacy and confidentiality; therefore, their names will not appear on the questionnaire. Only the researchers will collect and interpret the questionnaires. Each questionnaire will be referenced differently.

\section{Responsible Investing Survey Results}

Integrating environmental, social and governance considerations into the investment decision making process could assist in identifying, managing and mitigating potential ESG risks to achieve sustainable long-term investment outcomes. A score was allocated to each response provided by the respondents. The results of the Responsible Investing survey provided a snapshot of the perspectives on ESG integration from 29 South African asset managers.

Information indicates that $10 \%$ of the respondents implement PRI, 10\% implement CRISA and 62 percent implement both codes. Although $16 \%$ of the asset managers are not signatories to either PRI or CRISA, some of them indicated that they are either working towards becoming a signatory or they are currently incorporating the principles of the two codes in their investment decision-making process.

The majority (90\%) of the respondents indicated that they explicitly incorporated ESG factors in their investment processes. This suggests that most of the asset managers who participated in this survey pursue responsible investing with the integration of environmental, social and governance factors into their investment decision making. Given that $90 \%$ of the asset managers surveyed, affirmed that they explicitly incorporated ESG factors into their investment process, it is important to examine how ESG data of companies to potentially invest in, is accessed. It is stated that $31 \%$ of ESG data is accessed by engaging with management of companies while $30 \%$ of data is accessed via companies' sustainability reports. This is not surprising as listed companies in South Africa are required to provide reporting which incorporates the disclosure of ESG related information.

While $86 \%$ of the South African asset managers surveyed stated that they have an ESG policy, only 14\% indicated that they managed an ESG product. This is disappointing as ESG products would provide investors with the opportunity to become more 
familiar with ESG issues. It would also allow investors to test the value of environmental, social and governance integration. Emphasising the value of ESG integration in fund performance, if material, would be a very important driver.

It is stated that among the asset managers surveyed, all of them viewed corporate governance as the most important ESG factor in their investment process with a mean score of $55 \%$. The impact of the King IV code as well as the occurrence of some high profile corporate scandals recently (Fidentia and Steinhoff) could have driven this statistic. Environmental and social factors were ranked less important by the asset managers, reflecting a commonly held view that from a financial and management perspective, governance was the most important ESG factor.

Seventy-two percent of South African asset managers stated that part of the difficulty in measuring the impact of ESG considerations on returns is the lack of reliable and accurate ESG information available to investors. Sixty-nine percent of asset managers also stated that a lack of standardisation in ESG information also posed a considerable barrier to many responsible investors. Asset managers believe that this challenge is being addressed through regular engagement with companies on ESG issues. Eighty-three percent of South African asset managers stated that they are encouraging companies to address ESG issues in their reporting.

It is interesting to note that $66 \%$ of asset managers reported low investor education to be a barrier. There are still too many investors who are focussed on understanding companies' margins and growth models and too few questions are asked about ESG policies and practises. Consequently, asset managers have generally been reactive, rather than pro-active in providing investors with data relating to ESG issues. When asked whether they made their proxy voting record publicly available on their websites, $59 \%$ of the South African asset managers surveyed said they did not.

It would appear that investors are still focused on companies' quarterly results and whether investment expectations over the shorter term had been met. The indication provided by asset managers, is that $59 \%$ of clients are short term focused making it difficult for the value of ESG integration to be demonstrated. Clients however, may not be the only group who are short termed focused. Pension funds represent a significant component of the assets under management of investment managers. These funds generally take a long-term view of their investment horizon. Remuneration and rewards within the professional investment sector is based on making profit and incentives generally reward short-term performance. One can therefore deduce that maximising financial returns over the shorter term could be a barrier to the uptake of responsible investing assets by pension funds.
One of the least important barriers to responsible investing appears to be the negative perception of returns with an indication of $24 \%$ from the asset managers. This implies that the majority of the asset managers are of the view that there is no or little evidence that financial returns from Responsible Investments are lower than investments who do not consider ESG issues.

The biggest risk of being responsible investors is a lack of buyin as indicated by $70 \%$ of the respondents. This implies that the demand for RI offerings of clients is quite low. This lack of demand could undermine the expansion of RI offerings where $86 \%$ of asset managers surveyed currently do not have an RI product.

Seventy-six percent of South African asset managers cite client demand as the biggest driver of responsible investing. There have been a steady number of pension and retirement funds requesting asset managers to integrate ESG factors into their investment decision making process as well as in fund analysis. Furthermore $72 \%$ of the asset managers surveyed indicated that regulation has also raised the profile of ESG. If more stringent legislation would be introduced, it would be an even bigger driver of ESG as compliance would not be optional. Another driver which could be instrumental in increasing the awareness of ESG among mainstream investors could be the provision of evidence of increased financial return from RI products or assets. $62 \%$ of respondents believe that the risk versus return opportunities exists.

In 2011, Regulation 28 of the Pension Act was amended to include the consideration of any factor which could materially affect the sustainable long-term performance of assets when it comes to prudent responsible investing. This would include factors of an environmental, social and governance nature.

The Responsible Investing survey is a tool to assess the progress that South African asset managers are making towards the integration of ESG in their investment decision-making process. Based on responses to the survey, $83 \%$ of the asset managers surveyed scored above 50\%. These statistics are encouraging; however, asset managers should display evidence of them incorporating ESG factors in their investment decision-making process. Investors should be able to differentiate between asset managers just taking a tick-box approach and those who make a real effort to consider ESG factors. The Code for Responsible Investment in South Africa (CRISA) and the United Nations Principles for Responsible Investment (PRI) are good codes which have underlying principles guiding asset managers on how to incorporate responsible investing as it relates to their investment processes. Signatories to these two codes signify their intent to make an impact with respect to responsible investing. 
According to the statistics, 19 of the respondents implement PRI, 23 implement CRISA while $62 \%$ implement both codes. Although $16 \%$ of the asset managers are not signatories to either PRI or CRISA, some of them indicated that they are either working towards becoming a signatory or they are currently incorporating the underlying principles of the two codes in their investment decision-making process.

By inviting companies to complete the Responsible Investing questionnaire and incorporating the other four RI indicators (the B-BBEE rating, whether the company is a signatory to CRISA or PRI and its participation in the JSE SRI Index), a score can be allocated to the company. Taking the five RI indicators into account, five of the 29 asset managers scored more than 80 points in the Total SRI index. This is attributed to the fact that 4 of the managers participated in all of the RI indicators and all 5 of them are signatories to both the CRISA and PRI codes.

Of the respondents who participated, $69 \%$ scored more than 50 points in the Total SRI index out of a total of 100. This is encouraging as only $14 \%$ of the respondents were allocated points for participating in the JSE SRI index and 17\% did not score points as they are not signatories to either the CRISA or PRI codes.

\section{Research Data Conclusion}

It is encouraging to note that $84 \%$ of the managers are signatories to the CRISA and PRI codes. While the two are voluntary codes, self-regulation should be encouraged among the asset managers. The significance of ESG practices and processes will also be further enhanced by the investment and financial industry if they consider incorporating CRISA and PRI in future additions or changes to Regulation 28 of the Pension Funds Act.

\subsection{Research Data Conclusion: JSE/SRI Index}

Although the JSE/SRI Index aims to reflect best practice in corporate social responsibility (CSR) and highlight South African companies with good CSR records, only 4 of the 29 managers surveyed, participated in the index as at December 2017. Participation in this index is voluntary and has the potential of improving the standing of companies in terms of their commitment to investing responsibly. A more concerted effort should be made by South African asset managers to participate in this index as the derived benefits would be immense.

\subsection{Research Data Conclusion: Awareness of ESG}

The majority of local asset managers (90\%), express that ESG factors are considered in their investment processes. This indicate that asset managers are translating awareness into practice. The focus of asset managers continues to be on governance factors. The asset managers indicated a focus of $21 \%$ regarding environmental considerations, $21 \%$ was indicated for social concerns with governance at $55 \%$ being the most important factor for consideration.

\subsection{Research Data Conclusion: Risks to ESG}

Among the South African asset managers, $78 \%$ believed that the consideration of ESG factors resulted in a superior assessment of risk. However, asset managers are undecided if ESG considerations enhance returns. Only $35 \%$ of the asset managers believe that incorporating ESG factors into the investment decision-making process will result in improved returns. The majority of South African asset managers surveyed (72\%) express that part of the difficulty in evaluating the impact of ESG considerations on returns is the absence of reliable and accurate ESG data available to investors.

\subsection{Research Data Conclusion: Drivers of ESG}

The survey results show that asset managers believe there is increasing focus on long-term sustainability issues and enhanced risk/return opportunities. Demand from clients and regulation continues to play a key role. In the 2017 Responsible Investing survey, $76 \%$ of clients demanded responsible investment.

\subsection{Research Data Conclusion: Barriers to ESG}

Perceived barriers to RI include the lack of ESG data, uninformed investors and the focus of clients relating to RI only being fixed for a short term. The risk factors for RI include a lack of buy-in from stakeholders as well as insufficient ESG statistics and information.

\subsection{Research Data Conclusion: Addressing ESG Challenges} South African asset managers are addressing the ESG challenges by engaging with companies. All local asset managers indicated the engagement with organisations as part of their ownership responsibilities. $83 \%$ of asset managers followed this practice. Asset managers encourage organisations to improve their reporting disclosure on ESG factors: as a result, asset managers believe companies are feeling pressured to be more mindful about ESG issues (www.alexanderforbesinvestments.com).

\subsection{Research Data Conclusion: Total SRI Index}

The aim of this research was to identify an index that would be able to measure the ESG intent of companies. When the total scores are interrogated, it was found that some managers do not subscribe to either the CRISA or PRI codes, some do not participate in the JSE SRI Index and one asset manager is not BBBEE accredited. Due to the challenges faced by investors to measure ESG issues, the Total SRI Index could be used as a benchmark to test the integrity of claims made by asset managers in South Africa that they are investing responsibly.

\section{Limitations of this Study}

When aiming to expedite the RI process, it is necessary to establish where the issues lie regarding non-compliance with existing policies, codes and frameworks among South African asset managers. For the purposes of this study, the assumption 
has been made that the policies, codes and frameworks in place are good and well structured.

\section{Contributions of this Study}

This study contributes to the collection of studies in the field of responsible investing and sustainability and it specifically highlights the concept of RI in the South African context. The best practices, legislation and frameworks available that inform local RI practices are also highlighted. As organisations become more aware and start reporting in accordance with the best practices, legislation and frameworks, the available ESG data will become more consistent and of better quality. This study also contributes to discussing the importance of ESG considerations in investment decision-making and provides an overview of various RI strategies accessible to institutional investors, which will ensure financial returns in addition to environmental, social and governance considerations. The information provided and highlighted in this study would be particularly useful to asset managers, investors, academics, industry bodies as well as any interested parties in the financial services industry.

\section{Recommendations for Further Research}

Exploring the role of intermediaries such as analysts or trustees of pension funds in interpreting and translating ESG data produced by companies in order to make it more useful to investors would make for a purposeful study. Future research should focus on stakeholders' views on the various sustainability measurements to determine their impact, understanding of the measurements' objectives and reliance for decision-making. This should reveal which measurements are actually impacting and influencing stakeholders' decisions and actions. This would also help with the elimination of irrelevant measurements, thereby reducing perplexity among stakeholders and companies as to which measurements are useful.

\section{References}

- Alexander Forbes. (2016). Alexander Forbes Investments Responsible Investing Survey results. Available from: https://www.alexanderforbesinvestments.co.za/Responsible -Investing/Ri-Survey [Accessed 30 Sept. 2018]

- Alexander Forbes. (2017). Alexander Forbes Annual Manager Watch Survey. Available from: https://issuu.com/alexanderforbescomms/docs/managerwatc hsurvey_1d234dcdeafbbe?e=17857511/59307973

[Accessed 2 April 2019]

- Anney, V. N. (2014). Ensuring the Quality of the Findings of Qualitative Research: Looking at Trustworthiness Criteria. Journal of Emerging Trends in Educational Research and Policy Studies, 5(2):272-281.

- Association for Savings and Investments South Africa (ASISA), 2016. CRISA Press Release. Available from: https://www.asisa.org.za/wp-content/uploads/2017/05/crisapress-release-19-july-201.pdf [Accessed 11 March 2019]
- Austin, Z., \& Sutton, J. (2014). Qualitative Research: Getting Started. Journal of Hospital Pharmacy, 67(6):436$440 \underline{\text { Crossref }}$

- Bekjarovski, F., \& Brière, M. (2018). Shareholder Activism: Why Should Investors Care? Amundi Research. Available from:

- Bostrom, N. (2013). Existential Risk Prevention as Global Priority. Available from Crossref

- Braun, V., \& Clarke, V. (2006). Using thematic analysis in psychology. Qualitative Research in Psychology, (3):77101. Crossref

- Bryman, A., Bell, E., Hirschsohn, D. S., Du Toit, M., Van Aardt., \& Wagner, C. (2014). Research methodology: Business and management contexts. Cape Town: Oxford.

- Camilleri, M. A. (2017). Socially Responsible and Sustainable Investing: A Review and Appraisal. University of Malta, Department of Corporate Communication, Working Paper, 2017-01 Crossref

- Carhart, M. M. (1997). On Persistence in Mutual Fund Performance. The Journal of Finance, 52(1):57-82 Crossref

- Carroll, A. B. (1991). The Pyramid of Corporate Social Responsibility: Toward the Moral Management of Organizational Stakeholders. Business Horizons, 34(4):3948 Crossref

- CFA Institute, (2015). Environmental, social and governance issues in investing. Available from: https://www.cfainstitute.org//media/documents/article/position-paper/esg-issues-ininvesting-a-guide-for-investment-professionals.ashx [Accessed 23 March 2019]

- CFA Institute, (2019). Portfolio management process policy statement. Available from: https://www.cfainstitute.org/en/membership/professionaldevelopment/refresher-readings/2019/portfoliomanagement-process-investment-policy-statement

- Climent, F., \& Soriano, P. (2011). Green and Good? The Investment Performance of US Environmental Mutual Funds. Journal of Business Ethics, 103(2):275-287. Crossref

- Code for Responsible Investing in SA (CRISA). (2019). Committee on Responsible Investing by Institutional Investors in South Africa 2011. Available from: https://www.iodsa.co.za/page/CRISACode [Accessed 26 February 2019]

- Connelly, L. (2014). Ethical Considerations in Research, 23(1): 54-55. [online] Available from: https://www.ncbi.nlm.nih.gov/pubmed/24707669 [Accessed 30 Sept. 2018]

- Corporate Governance Review, (2013). South Africa. Available from: https://www.werksmans.com/wpcontent/uploads/2013/04/Law-Business-Research-

Corporate-Governance-Review-South-Africa.pdf [Accessed 23 March 2019]

- Creswell, J. W. (2014). Research design: Qualitative, Quantitative, and Mixed Methods Approaches, (4th ed.) Los Angeles, CA: Sage. 
- Creswell, J. W., \& Poth, C. N. (2018). Qualitative Inquiry and Research design: Choosing among five approaches, (4th ed.) London: Sage.

- Deloitte. (2014). Deloitte World Report. Available from: https://www2.deloitte.com/gz/en/pages/about-

deloitte/topics/global-report-2014.html [Accessed 30 Sept. 2018]

- Denzin, N.K., \& Lincoln, Y. (2005). The Sage Handbook of Qualitative Research. (Third ed.) California: Sage Publication

- Deutsche Asset \& Wealth Management. (2015). ESG \& Corporate Financial Performance: Mapping the global landscape. Available from: https://institutional.dws.com/content/_media/K15090_Acad emic_Insights_UK_EMEA_RZ_Online_151201_Final_(2). pdf [Accessed 23 March 2019]

- Eccles, N. (2010). UN Principles for Responsible Investment Signatories and the Anti-Apartheid SRI Movement: A Thought Experiment. Journal of Business Ethics, 95(3):415424. $\underline{\text { Crossref }}$

- Eccles, N.S., \& Viviers, S. (2011). The Origins and Meanings of Names Describing Investment Practices that Integrate a Consideration of ESG Issues in the Academic Literature. Journal of Business Ethics, 104(3):389-402. Crossref

- Elton, E., Gruber, M., Blake, C. (1995). The Persistence of Risk-Adjusted Mutual Fund Performance. NYU Working Paper No. FIN-95-018.

- Empowerdex Briefing. (2012). Black Economic Empowerment, scorecard compliance \& local procurement: Empowerdex briefing. Committee's 3rd term programme.

- Empowerdex, (2012). About us. [Online] Available from: http://www.empowerdex.com/\#rt-head-anchor / [Accessed 12 November 2018]

- Empowerdex. (2015). Empowerdex Rating. [Online] Empowerdex.com Available from: http://www.empowerdex.com/our-services/ratingprocess/itemlist/tag/empowerdex\%20rating [Accessed 30 Jul. 2016]

- Engshuber, W., Krumsiek, B., \& Burrett, R. (2011). NEI Investments. Available from: https://www.businesshumanrights.org [Accessed 30 Jul. 2016]

- EY, (2013). Responsible investment research. [Online] Available from: https://www.ey.com/Publication/vwLUAssets/The_State_of _Responsible_Investment_in_South_Africa/\$FILE/Respons ible\%20Investment\%20Study\%202013.pdf [Accessed 12 November 2018]

- Ferruz, L., Muñoz, F., \& Vargas, M. 2012. Managerial Abilities: Evidence from Religious Mutual Fund Managers. Journal of Business Ethics, 105(4):503-517. Crossref

- Fulton, M., \& Khan, B. (2012). Climate Change Investment Research 2 Sustainable Investing. Available from: http://www.psm.org.mx/wpcontent/uploads/downloads/Sust ainableInvesting2012.pdf [Accessed 30 Sept. 2018]
- GAA Accounting the Journal of the Global Accounting Alliance, (2010). Available from: http://www.gaaaccounting.com/2010/10/page/7/ [Accessed 03 October 2018]

- Galema, R., Plantiga, A., \& Scholtens, B. (2008). The Stocks at Stake: Return and Risk in Socially Responsible Investment. Journal of Banking and Finance, 32(12): 26462654. Crossref

- Gao, Y. (2009). Bondholder Activism and Delay in Financial Reporting. Document de travail No. 1365008 disponible sur SSRN. Available from: https://ssrn.com/abstract $=1365008$ [Accessed 03 October 2018] Crossref

- Giamporcaro, S., \& Pretorius, L. (2012). Sustainable and responsible investment (SRI) in South Africa: A limited adoption of environmental criteria. Investment Analysts Journal, 75:1-18. $\underline{\text { Crossref }}$

- Gillan, S. L., \& Starks, L. T. (2007). The Evolution of Shareholder Activism in The United States. Journal of Applied Corporate Finance, 19(1):55-73 $\underline{\text { Crossref }}$

- Gladysek, O., \& Chipeta, C. (2012). The impact of Socially Responsible Investment Index constituent announcements on firm price: evidence from the JSE. South African Journal of Economic and Management Sciences, 15(4). Crossref

- Global Corporate Governance Forum (2003). [Online] Available from: http://www.gcgf.org/ [Accessed 03 Dec. 2018]

- Global Sustainable Investment Review (GSIR), (2016). Available from: http://www.gsi-alliance.org/wpcontent/uploads/2017/03/GSIR_Review2016.F.pdf [Accessed 03 October 2018]

- Harvard Business review, 2016. The comprehensive business case for sustainability. Available from: https://hbr.org/2016/10/the-comprehensive-business-casefor-sustainability [Accessed 24 February 2019]

- Henriksson, R., Livnat, J., Pfeifer, P., \& Stumpp, M. (2018). Integrating ESG in Portfolio Construction. [Online] qma.com.

Crossref https://www.qma.com/assets/pdf/QMA_Integrating_ESG_i n_Portfolio_Construction.pdf [Accessed 24 February 2019]

- Herringer, A., Firer, C., \& Viviers, S. (2009). Key challenges facing the socially responsible investment (SRI) sector in South Africa. Investment Analysts Journal, (70):11-26. $\underline{\text { Crossref }}$

- Huberman, G. (2005). Arbitrage Pricing Theory. Staff Report, Federal Reserve Bank of New York.

- Iliev, P., \& Lowry, M. (2014). Are mutual funds active voters? The Review of Financial Studies, 28(2):446-485. Crossref

- Inderst, G., \& Stewart, F. (2018). Incorporating Environmental, Social and Governance (ESG) Factors into Fixed Income. Crossref https://openknowledge.worldbank.org/bitstream/handle/.../1 25442-WP-PUBLIC.pdf [Accessed 26 October 2018] 
- Institute of Directors in Southern Africa (IODSA). (2011). Code for responsible investing in South Africa (CRISA). Johannesburg: Institute of Directors in Southern Africa.

- International Finance Corporation (IFC). (2011). Sustainable investment in Sub-Saharan Africa.

- Iraya, C. (2018). How Socially Responsible Investment Affect Performance of Mutual Funds in Kenya. Journal of Business \& Economic Policy ,5(1).

- lrs.org.za, (n.d). The CRISA Code in summary. [online] Available from: http://www.lrs.org.za/docs/The\%20CRISA\%20Code\%20su mmary.pdf [Accessed 12 November 2018]

- Jansson, M., \& Biel, A. (2011). A motive to engage in sustainable investment: a comparison between institutional and private investors. Available from: https://econpapers.repec.org/article/wlysustdv/v_3a19_3ay_ 3a2011_3ai_3a2_3ap_3a135-142.htm [Accessed 03 October 2018] Crossref

- Jensen, M.C. (1968). The Performance of Mutual Funds in the Period 1945 - 1964. Journal of Finance, 23(2):389-416. Crossref

- Joana, P., \& Cortez, M.C. n.d. (2014) Social screening and mutual fund performance: international evidence. Available from: $\quad$ editorialexpress.com/cgibin/conference/download.cgidb_name=financeforum $17 \& \mathrm{pa}$ per_id=96 [Accessed 03 October 2018]

- JSE, (2014). Annual Integrated Report. Available from: ttp://www.jsereporting.co.za/ar2014/ [Accessed 03 October 2018]

- JSE, (2015). Annual Integrated Report. Available from: ttp://www.jsereporting.co.za/ar2015/ [Accessed 03 October 2018]

- Kanso, A. M., Kitchen, P. J. \& Nelson, R. A. (2019). BP and the Deepwater Horizon oil spill: A case study of how company management employed public relations to restore a damaged bran. Journal of Marketing Communications. Crossref

- Karnani, A. (2010). The case against corporate social investment. Available from: http://online.wsj.com/article/SB1000142405274870333800 4575230112664504890 [Accessed 03 October 2018]

- Kempf, A., \& Osthoff, P. (2007). The Effect of Socially Responsible Investing on Portfolio Performance. Journal European Financial Management, 13(5):908-922Crossref

- Kempf, A., \& Osthoff, P. (2008). SRI Funds: Nomen est Omen. Journal of Business Finance \& Accounting, 35(9):1276-1294. Crossref

- Kern-Stone, R., \& Mishra, S. (2019). Transnational Media: Concepts and Cases. Massachusetts: Wiley-Blackwell

- Khan, M., \& Davies, H. (2015). UNCTAD's Investment Policy Framework Explores the Complex Issues and Opportunities of Investment for Sustainable Development. Available

from: http://investmentpolicyhub.unctad.org/Upload/Documents/ POLICY\%20FRAMEWORK\%202015_WEB_1.pdf.
- Khan, M., Serafeim, G., \& Yoon, A. 2015. Corporate Sustainability: First Evidence on Materiality. Available from: https://hbswk.hbs.edu/item/corporate-sustainabilityfirst-evidence-on-materiality. [Accessed 03 October 2018] Crossref

- Kivunja, C., \& Kuyini, A.B. (2017). Understanding and Applying Research Paradigms in Educational Contexts. International Journal of Higher Education, 6(5):26-41. Crossref

- Krosinsky, C., Robins, N., \& Viederman, S. (2011). Evolutions in sustainable investing. Hoboken, N.J.: Wiley. Crossref

- Krosnick, J.A. (2009). Questions and Questionnaire Design. Available from: https://web.stanford.edu/dept/communication/faculty/krosni ck/docs/2009/2009_handbook_krosnick.pdf [Accessed 28 March 2019]

- Kupfer, T. (2018). Does Socially Responsible Investing Work as Advertise? [Online] National Review. Available from: https://www.nationalreview.com/corner/esginvesting-does-it-work/ [Accessed 02 Dec. 2018]

- Kurtz, L. (2005). Answers to Four Questions. The Journal of Investing, 14 (3):125-140. Crossref

- Laedre, O., Haavaldsen, T., Bohne, R., Kallaos, J., \& Lohne, J. (2015). Determining Sustainability Impact Assessment Indicators. Impact Assessment and Project Appraisal, 33(2):98-107. Crossref

- Li, F., Sherrerd, K., \& Treussard, J. (2018). Unlocking the Performance Potential in ESG Investing. [Online] Research Affiliates. Available from: https://www.researchaffiliates.com/documents/659Unlocking-the-Performance-Potential-of-ESGInvesting.pdf [Accessed 02 Dec. 2018]

- Lynx Investment Advisory, (2018). Investing for the Greater Good: Theory Vs. Practice. [Online] Available from: https://seekingalpha.com/article/4174141-investing-greatergood-theory-vs-practice [Accessed 03 Dec. 2018]

- Mackintosh, J. (2018). If You Want to Do Good, expect to Do Badly. [Online] The Wall Street Journal (wsj.com). Available from: https://www.wsj.com/articles/if-you-wantto-do-good-expect-to-do-badly-

1530185698?mod=hp_lista_pos1 [Accessed 01 Dec. 2018]

- Maharaj, K. (2012). Deepwater Horizon Oil Spill. Anaheim University Press.

- Mail and Guardian, (2013). BEE is Flawed and should be Scrapped. Available from: https://mg.co.za/article/2013-0118-bee-is-flawed-and-should-be-scrapped [Accessed 12 November 2018]

- Mallett, J., \& Michelson, S. (2010). Green Investing: Is it Different from Socially Responsible Investing? International Journal of Business, 15(4):395-410.

- Mansberger, L. (2012). The rapid rise of Sustainable and Responsible Investing: From Marginal to Mainstream? Available from: https://www.uoguelph.ca [Accessed 30 Sept. 2018] 
- Mans-Kemp, N. \& Viviers, S. (2016). Responsible investing in South Africa, in T.Hebb, J.P. Hawley, A.G.F. Hoepner, A.L. Neher \& D.Wood (eds). The Routledge handbook of responsible investment. Abingdon: Routledge. 99-114.

- Mapping the Global Landscape. Available from: https://institutional.dws.com/content/_media/K15090_Acad emic_Insights_UK_EMEA_RZ_Online_151201_Final_(2). pdf [Accessed 29 October 2018]

- Marchand, M. (2012). Behavioral biases in financial decision making. Available from: http://arno.uvt.nl/show.cgi?fid=129741 [Accessed 30 Sept. 2018]

- Martínez-Mesa, J. (2016). Sampling: how to select participants in my research study? [online] Available from: https://www.ncbi.nlm.nih.gov/pmc/articles/PMC4938277/ [Accessed 30 Sept. 2018]

- Mattison, R., Trevitt, M. \& van Ast, L. (2011). Universal ownership: Why environmental externalities matter to institutional investors. Principles for Responsible Investment and UNEP Finance Initiative.

- McCahery, J. A., Sautner, Z., \& Starks, L. T. (2016). Behind the scenes: The corporate governance preferences of institutional investors. The Journal of Finance, 71(6):29052932. Crossref

- McDermid, F., Peters, K., Jackson, D., \& Daly J. (2014). Conducting qualitative research in the context of pre-existing peer and collegial relationships. [online [Accessed 03 October 2018] Crossref

- McKinsey and Company, (2019). Why to why not sustainable investing as the new normal. Available from: https://www.mckinsey.com/industries/private-equity-andprincipal-investors/our-insights/from-why-to-why-notsustainable-investing-as-the-new-normal [Accessed 10 March 2019].

- McMillan, J.H., \& Schumacher, S. (2010). Research in education: evidence-based inquiry. (7th ed.) Boston: Pearson

- Mercer, D. (2009). Sustainability Science Partnerships: A View from the Antipodes. Crossref

- Mertens, D. M. (2010) Research and evolution in education and psychology. (3rd ed.) London: Sage

- Morgan, A., Poulsen, A., Wolf, J., \& Yang, T. (2011). Mutual funds as monitors: Evidence from mutual fund voting. Journal of Corporate Finance, 17(4):914-928. Crossref

- Morgan, D. L. (2014). Pragmatism as a Paradigm for Social Research. Qualitative Inquiry. 20:1045-1053. Crossref

- Moser, K. (2010). Epistemology. [Online]. Available from: https://www.researchgate.net [Accessed 02 Dec. 2018]

- MSCI, 2016. PRI and MSCI Global guide to Responsible Investment Regulation. Available from: https://www.msci.com/documents/1296102/0/PRI_MSCI_ Global-Guide-to-Responsible-Investment-

Regulation.pdf/ac76bbbd-1e0a-416e-9e83-9416910a4a4b [Accessed 11 March 2019]
- Muñoz, F., Vargas, M., \& Marco, I. (2014). Environmental Mutual Funds: Financial Performance and Managerial Abilities. Journal of Business Ethics, 124(4):551-569. $\underline{\text { Crossref }}$

- Muteza, A. (2013). Credit Rationing and Risk Management for SMEs: The Way Forward for South Africa Article in Corporate Ownership and Control, 10(2):153-163. Available from: doi:10.22495/cocv10i2c1art1[Accessed 03 October 2018] Crossref

- Nel, W. S. (2011). The Application of the Capital Asset Pricing Model (CAPM): A South African Perspective. African Journal of Business Management, 5(13):5336 5347.

- Nelson, E. (2018). Too good to be true: Sustainable investing risks becoming a victim of its own success. [Online] qz.zom. Available from: https://qz.com/1490365/esg-investingrisks-becoming-a-victim-of-its-own-success [Accessed 25 Feb. 2019]

- Neuman, W. L. (1997). Social Research Methods. Qualitative and Quantitative Approaches. Boston, London Toronto: Allyn \& Bacon.

- Neuman, W. L. (2007). The Meanings of Methodology. In L. W. Neuman (Ed.), Social Research Methods: Qualitative and Quantitative Approaches (3rd ed.). Allyn and Bacon.

- Ngwakwe, C., \& Mtsweni, S. (2016). Extent of Sustainability Assurance in South African Mining Companies. Journal of Accounting and Management, 6(1):59-74

- Nieswiadomy, R. M. (2012). Foundations of Research, 6th Edition. [online] Available from: https://www.pearson.com/us/highereducation/.../Nieswiado my.../PGM253860.html [Accessed 30 Sept. 2018]

- Ntoi, H. (2010). The impact of corporate social responsibility on the corporate financial performance of companies listed on the Johannesburg Securities Exchange. Available from: https://repository.up.ac.za/bitstream/handle/2263/25621/dis sertation.pdf;sequence $=1$ [Accessed 30 Sept. 2018]

- Oekom Research. (2013). The Impact of SRI: An Empirical Analysis of the Impact of Socially Responsible Investments on Companies. Available from: https://www.researchgate.net [Accessed 03 October 2018]

- Price Waterhouse Cooper (PWC). (2012). Doing the right thing Annual Report 2012. Available from: https://www.pwc.co.uk/assets/pdf/annual-report-2012.pdf [Accessed 03 October 2018]

- Reilly, F. \& Brown, C. (2000). Investment Analysis and Portfolio Management, sixth edition, The Dryden Press.

- Revelli, C. (2017). Socially Responsible Investing (SRI): From Mainstream to Margin? Journal Research in International Business and Finance, 39:711-717. Crossref

- Rhodes, M. J. (2010). "Information Asymmetry and Socially Responsible Investment” Journal of Business Ethics, 95:145 - 150. $\underline{\text { Crossref }}$

- Rintoul, R. (2015). ESG Investing: The key to Volkswagen. Available from: http://www.funds-europe.com/esg- 
investing-the-key-to-volkswagen [Accessed 12 November 2018]

- Saigal, K. (2014). Africa's rising stars: Vuyo Jack, cofounder and executive chairman of Empowerdex. [online] Euromoney.com. Available from: https://www.euromoney.com/article/b12kjzj7btgpc0/africas -rising-stars-vuyo-jack-cofounder-and-executive-chairmanof-empowerdex [Accessed 12 November 2018]

- Saunders, M., Lewis, P. \& Thornhill, A (2012). Research Methods for Business Students. London: Pearson.

- Schieler, M. (2015). Measuring Country Intangibles: RobecoSAM's Country Sustainability Ranking. Switzerland: RobecoSAM.

- Schot, J., \& Steinmuller, E.W. (2018). Three frames for innovation policy: R\&D, systems of innovation and transformative change. Available from: [Accessed 17 March 2019] Crossref

- Schroders. (2017). Understanding sustainable investment and ESG investment terms. Available from: https://www.schroders.com/getfunddocument/?oid=1.9.276 0595 [Accessed 23 October 2018]

- Schroders Global Investor Study. (2017). Schroders Global Investor Study 2017: Global perspectives on sustainable investing. Available from: https:/www.schroders.com/en/sysglobalassets/digital/insig hts/2017/pdf/global-investor-study-

2017/schroders_report_sustainable-investing_final.pdf [Accessed 24 March 2019]

- Sievanen, R., Rita, H. \& Scholtens, B. (2013). The Drivers of Responsible Investment: The Case of European Pension Funds. Journal of Business Ethics, 117(1):137-151. Crossref

- Silva, F., \& Cortez, M. (2016). The Performance of US and European Green Funds in Different Market Conditions. Journal of Cleaner Production, 135:558-566. Crossref

- South African Government. (2019). Environment. [Online] gov.za. Available from: https://www.gov.za/aboutsa/environment [Accessed 24 February 2019]

- Sulkowski, A. (2015). All Things Sustainability. Available from: https://adamsulkowski.com/ [Accessed 24 October 2018]

- Sun, M., Nagata, K., \& Onoda, H. (2011). The investigation of the current status of socially responsible investment indices. Journal of Economics and International Finance, 3(13):676-684.

- Staadt, J. (2012). Redesigning a project-oriented organization in a complex system: A soft systems methodology approach. International Journal of Managing Projects in Business, 5(1):51-66. Crossref

- Swedish Investment Fund Association. (2012). Responsible Investments - About funds, ethics and sustainability. Stockholm: Brasel.

- Syed, A.M. (2017). Environmental, social and governance (ESG) criteria and preference of managers. Cogent Business \& Management, 4(1), 1340820. Crossref
- Thabane, T., \& Snyman-Van Deventer, E. (2018) Pathological corporate governance deficiencies in South Africa's state-owned companies: A critical reflection. PER/PELJ2018 (21). Crossref

- Theron, P. M. (2015). Coding and data analysis during qualitative empirical research in Practical Theology, 49(3). Crossref

- United Nations Environment Programme Finance Initiative (UNEPFI). (2010). The State of Responsible Investment in South Africa. Available from: http://www.unepfi.org/fileadmin/documents/The_State_of_ Responsible_Investment_01.pdf [Accessed 30 September 2018]

- United Nations Environment Programme Finance Initiative, (2017). Fiduciary duty in the 21st century - SA Roadmap. Available from: https://www.unepfi.org/wordpress/wpcontent/uploads/2017/06/Fiduciary-duty-in-the-21stcentury-SA-roadmap.pdf [Accessed 11 March 2019]

- UNPRI. (2019). Principles for Responsible Investment Report. Available from: https://www.unpri.org/fixedincome/esg-screening-in-fixed-income-investing/36.article [Accessed 10 March 2019]

- Urwin, R., Worldwide, W., \& Woods, C. (2012). Sustainable Investing Principles: Models for Institutional Investors, Oxford University Press.

- van der Ahee, G., \& Schulschenk, J. (2013). The State of Responsible Investment in South Africa. Research Report. South Africa: Ernst \& Young.

- van der Merwe, C.M., \& Ferreira, P. (2014). The association among the seven elements of the black economic empowerment score and market performance. South African Journal of Economic and Management Sciences 17 (5) Crossref

- van Dijk-de Groot, M., \& Nijhof, A. H. J. (2015). Socially Responsible Investment Funds: a review of research priorities and strategic options. Journal of Sustainable Finance \& Investment, 5(3):178-204. Available from: Crossref

- Viviers, S., Bosch, J., Smit, E. \& Buijs, A. (2009). Responsible investing in South Africa. Investment Analysts Journal, 69:3-16. Crossref

- Vogt, P. W., Gardner, D. C. \& Haeffele, L. M. (2012). When to Use What Research Design. [online] Available from: https://www.guilford.com/excerpts/vogt.pdf [Accessed 30 Sept. 2018]

- Walliman, N. (2011). Research Methods: The Basics. New York: Routledge. Crossref

- Wang, Q., Dou, J., \& Jia, S. (2015). A Meta-Analytic Review of Corporate Social Responsibility and Corporate Financial Performance: The Moderating Effect of Contextual Factors. Business \& Society, 55(8):1083-1121. Crossref

- Wasilewski, S.M. (2009) Time, Functions and Processes: Towards Sustainable Investment Risk Benchmarks. 22:345349. Crossref 
- Wisebrod, M. (2007). Social Impact Ratings: How to Make Responsible Investment Appealing. [Online] Available from: https://www.cairn.info/revue-financeet-bien-commun-2007-2-page-29.htm [Accessed 02 Dec. 2018] Crossref

- Wood, M. J. \& Ross-Ker, J. (2011). Basic Steps in Planning Nursing Research: From Question to Proposal. Available from: www.jblearning.com [Accessed 30 Sept. 2018]

- X-Chequer, (2012). X-Chequer Fund Management. Available from: https://www.xfm.co.za/team/ [Accessed 30 Sept. 2018] 